Article Type: Research Paper

\title{
Product Innovation Strategy and Dynamic Environment Against the Improvement of Company Performance at MSME in Kulon Progo
}

\author{
Wulan Dari ${ }^{1 *}$ and Dessy Isfianadewi ${ }^{1}$
}

Abstract: This study aims to improve company performance at MSME by implementing product innovation strategies supported by dynamic environments. This research used a quantitative approach and the structural equation model (SEM) method. Data collection employed questionnaire methods, and data analysis was tested using AMOS. This study's population was MSMEs registered at the Cooperatives and MSME Office in Kulon Progo Regency in 2019. Besides, the respondents sampled in this study were 200 MSMEs focusing on the culinary, handicraft, and fashion industry sectors. This study's results proved that the dynamic environment positively and significantly influenced product innovation strategies. Then, product innovation positively and significantly affected firm performance. Furthermore, the dynamic environment had a positive and significant influence on firm performance. The product innovation strategy mediated the relationship between the dynamic environment and firm performance. This study contributes to the MSMEs' owners being aware of the importance of improving company performance by continuously implementing product innovation strategies because consumers are smarter to choose and decide where and what products to consume as their needs and desires' fulfillment. This product innovation strategy could mediate the influence of the dynamic environment and company performance.

Keywords: Product innovation; Dynamic environment; Company performance.

\section{Introduction}

In the era of globalization, more and more large-scale companies in Indonesia are competing with each other. This trend is indicated by increasingly intense competition. In a competitive business environment, the company must have the ability to distinguish itself in competition to maintain its viability. Based on the globalization phenomenon, it becomes essential for every company to have a strategic way of thinking by measuring performance. The performance measurement's existence is expected to improve the performance's achievement.

Micro, Small, and Medium Enterprises (MSME) have an essential and strategic role in national economic development. In addition to playing a role in economic growth and employment, MSME also plays a role in distributing development results. Based on Table 1 quoted from Bappeda DIY (2019), it was proven that after the 1997-1998 economic crisis, the 
number of MSME did not decrease; instead, it continued to increase. The table shows that from 2016-2019, the number of MSME units with a large number of industrial units had a very different number of units. It proved that the number of MSME units per year has always increased and is still above the number of large industrial units in DIY. It indicated that MSME was not affected by the crisis when the monetary crisis hit Indonesia in 1997-1998.

Table 1 Data on Number of MSME Units and Number of Large Industrial Units in DIY Region

\begin{tabular}{|clllll|}
\hline Number & Subelement & \multicolumn{3}{c|}{ Year } \\
& & 2016 & 2017 & 2018 & $\mathbf{2 0 1 9}$ \\
\hline $\mathbf{1}$ & Microbusiness & 130.525 & 135.799 & 141.991 & $\mathbf{1 4 3 . 6 1 0}$ \\
$\mathbf{2}$ & Small business & 59.655 & 62.042 & 64.896 & $\mathbf{6 5 . 6 4 2}$ \\
$\mathbf{3}$ & Medium & 36.031 & 37.472 & 39.196 & $\mathbf{3 9 . 6 4 7}$ \\
& Business & & & & \\
$\mathbf{4}$ & Large Industry & 12.408 & 12.904 & 13.498 & $\mathbf{1 3 . 6 5 3}$ \\
\hline
\end{tabular}

Source: BAPPEDA DIY (2019)

The current era of globalization development has an increasingly fierce impact on business competition, including MSME. The existence of a dominant Micro and Small Business Sector as a national economic actor is also a vital subject in development, particularly in the context of expanding business opportunities for new entrepreneurs and employment and reducing unemployment (depkop.go.id, 2019). The companies' types, especially those based on MSME, must undoubtedly have a business competition strategy plan appropriate and efficient in carrying out their business processes not to be left behind by other business competitors and can run according to the initial establishment objectives of the company or organization. This excellent opportunity is, in fact, not supported by the readiness of the company or organization, management, and production to be innovative, creative, and always oriented to market needs. As a result, the MSME's ability in Indonesia to compete with other business actors is still low. As an entity that carries out activities such as business or industry in general, MSME requires proper strategic planning, innovation, and product quality improvement. Thus, it needs to be designed as an innovation strategy where the strategy will ultimately improve company performance. The company can face a very dynamic business environment that demands business activities always to innovate continuously. (Dibrell, Davis, \& Craig, 2008); (Budiarto, Prabowo, \& Herawan, 2017). The following Table 2 explains the criteria for MSME based on Law RI No. 20 (2008). Table 2 facilitates classification and finds out the differences between micro, small, and medium enterprises. 
Dari \& Isfianadewi

Product Innovation Strategy and Dynamic Environment Against ...

Table 2 MSME Criteria According to Law RI No. 20 of 2008

\begin{tabular}{|c|c|c|c|}
\hline Explanation & Microbusiness & Small business & Medium Business \\
\hline \multirow{3}{*}{$\begin{array}{l}\text { BAB II } \\
\text { Principle and } \\
\text { Purpose } \\
\text { Clause } 6\end{array}$} & $\begin{array}{l}\text { Has a maximum net } \\
\text { worth of } \mathrm{Rp}\end{array}$ & $\begin{array}{l}\text { Has a net asset of } \\
\text { more than } \mathrm{Rp}\end{array}$ & $\begin{array}{l}\text { Has a net worth of } \\
\text { more than }\end{array}$ \\
\hline & $\begin{array}{l}50,000,000.00 \text {, } \\
\text { excluding land and } \\
\text { buildings for } \\
\text { businesses }\end{array}$ & $\begin{array}{l}50,000,000, \text { up to a } \\
\text { maximum of } R p \\
500,000,000.00\end{array}$ & $\begin{array}{l}\text { Rp. } 500,000,000.00 \\
\text { up to a maximum of } \\
\text { Rp10,000,000,000.00 } \\
\text { excludes land and } \\
\text { buildings for } \\
\text { business locations }\end{array}$ \\
\hline & $\begin{array}{l}\text { Has annual sales } \\
\text { results of at most } \\
\text { Rp. } 300,000,000.00\end{array}$ & $\begin{array}{l}\text { Has annual sales } \\
\text { results of more than } \\
\text { Rp. } 300,000,000.00 \text { up } \\
\text { to a maximum of } \\
\text { Rp2, } 500,000,000.00\end{array}$ & $\begin{array}{l}\text { Has annual sales } \\
\text { results of more than } \\
\text { Rp } 2,500,000,000.00 \\
\text { up to a maximum of } \\
\text { Rp } \\
50,000,000,000.00\end{array}$ \\
\hline
\end{tabular}

Source: Law RI No.20 (2008)

The Kulon Progo Regency Cooperative and SME Office stated that the poverty rate in Kulon Progo Regency in 2018 reached 18\% and was the highest among regencies/cities in DIY. Therefore, the Kulon Progo Regency Government tried to overcome this with various programs massively. One of them was through developing cooperatives and MSME as the spearhead of people's economy. Besides, improving Kulon Progo's local product competitiveness and facing the Industrial Revolution 4.0, the MSME are demanded to be more dynamic, innovative, and revolutionary not to be involved with these increasingly complex and complicated conditions. Based on the economic sector data of the Kulon Progo Regency/City (2019), currently, the number of MSME in the Kulon Progo Regency as of December 2019 was 40,730 units (Department of Cooperatives and MSME, 2019). Meanwhile, the number of productive poor MSME was 1,281 units. Thus, increasing competitiveness that focuses on product innovation strategies must be exceptionally supported because it is related to the collaboration developed by various partners in Kulon Progo, such as partnerships with large businesses, namely PT Indomarco Prismatama, with cooperatives in Kulon Progo in the form of People Owned Stores (TOMIRA), Wheat Flour Producer PT Sriboga, and hundreds of SMEs in the entire Kulon Progo District (Abdul, 2019).

Over time, many problems are faced by SMEs; one of them is product innovation (Lee, Kim, Choi, \& Lee. 2009). Many researchers have conducted research related to the MSME's performance in Indonesia. However, this problem is still critical because most MSME in Indonesia are traditional companies with low productivity and lack of product innovation (Tambunan, 2011). Further, performance measurement is a process of evaluating work progress towards targets in a corporate entity. In line with the technology and science development, the community as consumers will be more selective in choosing products needed so that companies must anticipate changes in the environment, in this case, a product demand. SMEs must start thinking to defeat their competitors and change their way of thinking, which previously only thought to seek profit; now, they must think to win the competition through an innovation strategy and dynamic environment (Moeheriono, 2012). 
The innovation's role in boosting company performance includes all essential aspects that can add value to its competitiveness: processes, products, markets, management, and others. According to Klein and Sorra (1996), innovation activities generally have two models. First, the source-based model is a model based on the developer's perspective or innovation source. Developers create new products or services with original ideas for final product marketing. Second, the user-based stage model is based on the user's perspective. The company makes an innovation process based on the awareness of the need or opportunity for change to link innovation in user behavior. Organizations in innovation need to develop a formal and comprehensive strategy. This strategy expresses the organization's innovation goals, namely by explaining what will be innovated and how. Variable dimensions of the innovation strategy consist of leadership orientation, process innovation, product innovation, internal innovation sources, external innovation sources, innovation implementation, and investment levels (Zahra \& Das, 1993).

\section{Literature Review and Hypotheses Development}

\section{The dynamic environment influences the product innovation strategy}

Research conducted by Popa, Acosta, and Conesa (2017) has proven the influence of a dynamic environment on innovation. This study took a sample of 429 SMEs in Spain, and it had very valuable benefits for SMEs in implementing or intending to implement an innovation strategy. The dynamic environment influences innovation because the environment's power is considered to produce tremendous pressure in the innovation strategies' formation and outcome. Subsequent research aimed at revealing how dynamic environmental conditions impacted leadership has led to innovation (Jansen, Vera, \& Crossan, 2009). Regarding the dynamic environment context with product innovation, there was a positive relationship between the dynamic environment and product innovation, which was the strongest factor (Acosta, Popa, \& Conesa, 2018).

\section{$\boldsymbol{H}_{1} \quad$ :The dynamic environment influences the product innovation strategy.}

\section{The product innovation strategy influences the company's performance}

Muchlas (2015) revealed that innovation is a vital process in general, and if it is carried out based on the product's forward vision and is appropriate in accordance with the product and business's characteristics. It was proven to improve SMEs' performance. Simultaneous test results showed that innovation source, leadership orientation, innovation type, and innovation level were proven to affect SMEs' performance significantly. Individually, the leadership orientation variables and innovation type significantly influenced SMEs' performance. Meanwhile, innovation sources and innovation levels showed no significant effect on SMEs' performance. Innovation is a self-concept consisting of several dimensions of various types. Product innovation is developing defined or new components, features, and new technologies for new 
products. Product innovation has attracted a large amount of attention in the literature (Carranza, 2010); (Corsino \& Gabriele, 2010); (Fontana \& Nesta, 2009); (Kusiak, 2009), and research have shown its direct effect on company performance. Research carried out by Han and Gao (2019), with empirical tests from survey data collected from 303 companies in China, supported a positive relationship between innovation strategies with company performance. It was because, specifically, the innovation strategy could improve competitiveness associated with company performance.

$\boldsymbol{H}_{2}$ : Product innovation strategies affect company performance.

\section{Dynamic environment influences company performance}

Research conducted by Acosta et al. (2018) confirmed a positive relationship between a dynamic environment and company performance. The research was conducted on respondents as many as 429 manufacturing SMEs in Spain. Besides, research done by Sanchez, Morales, \& Rojas (2017) analyzed how factors such as the environment could influence organizational performance. The hypothesis was empirically tested using a sample of 160 existing technology companies in Europe. A positive relationship was found about the environment in which the organization operated required it to pay attention to changes in their environment to maintain and improve its performance.

$\mathrm{H}_{3} \quad$ :Dynamic environment influences company performance.

\section{Dynamic environment influences company performance through product innovation strategy}

Research uncovered that companies in an unstable environment and a high environmental competition level would increase their innovation to achieve higher performance. Companies that can survive under unfavorable environmental conditions must generally achieve higher profitability and efficiency level through a high innovation level (Raju, Lonial, \& Crum, 2011). The literature has shown that business performance did not only depend on environmental conditions but also balanced with an innovation strategy (Omri, 2015). In general, a dynamic environment refers to the change rate and the environmental variability level. Therefore, MSME can adopt a product innovation strategy in a complex and uncertain environment because an environment offers important opportunities related to growing market demand (Schweitzer, Gassmann, \& Gaubinger, 2011).

$\mathrm{H}_{4} \quad$ : Dynamic environment influences company performance through product innovation strategies. 
Dari \& Isfianadewi

Product Innovation Strategy and Dynamic Environment Against ...

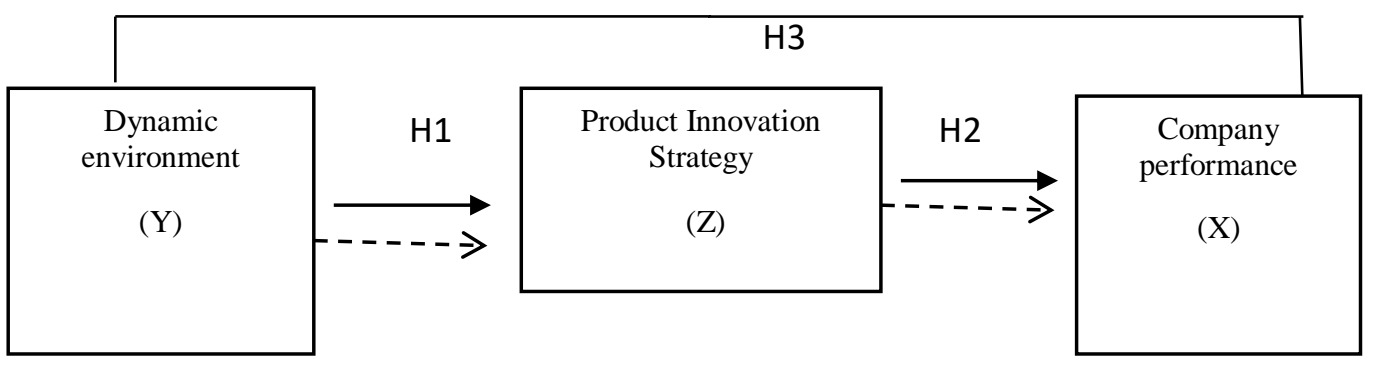

Figure 1 Framework of Thinking

\section{Research Method}

The population in this study was MSMEs in Kulon Progo district in 2019, amounting to 40,730 . The number consisted of various economic sectors: agriculture and fisheries, manufacturing, building, trade, hotels, restaurants, transportation and communication, finance, leasing, and services. This study's sample determination employed probability sampling techniques. This study's sampling design type was cluster sampling. It is a heterogeneous sampling and heterogeneous characteristics of population members in one group. In this case, the population was very heterogeneous, consisting of various economic sectors, then classified in different industries. The sample in this study chose MSME engaged in the economic sector of the manufacturing industry. In the processing industry, various types of business units were engaged in different fields. The sample taken was enough to take the processing industry, which focused on culinary, handicraft, and fashion.

This study's total sample would be determined by researchers as many as 200 samples. Researchers distributed 200 questionnaires in the form of hardcopy and google form. The questionnaire's distribution was carried out to the maximum and always ensured that the returned questionnaires were also 200, and in the end, the returned questionnaires were 200. The questionnaire was distributed by distributing it to MSME's owners. The decision to determine a sample of 200 was based on Hair Jr, Black, Babin, and Anderson (2014), who considered a research model using the Structural Equation Modeling (SEM) model. In SEM, the ideal number of samples was between 100-200 and must consider the number of model indicators. The number of samples can be 5-10 of the number of indicators. In this study, there were 21 indicators so that the number of samples could range from $105-210$ respondents.

\section{Measurement of Research Variables}

\section{Independent Variable}

This study's independent variable was a dynamic environment, an environment that can affect business/company activities' course. It could be influenced by the level and stability of changes in the company's external environment. According to $\mathrm{Wu}$ (2010), to measure dynamic environments, the following indicators can be used: 
- Products or services in the industry are updated quickly.

- Business actors have difficulty predicting changes in competitors.

- Technology is developing rapidly.

- Business practitioners have difficulty predicting changes in customer needs.

- Customers often ask for new products and services.

- The market has changed in a year.

- Demand for the number of products or services in the market changes very often.

\section{Dependent Variable}

The dependent variable in this study was the company performance, which resulted from the achievement level or company/business's achievement within a specific time it carried out a business activity. According to Munizu (2010); Rehman, Wong, Sultan and Merrilees (2018), to measure company performance, the following indicators can be used:

- sales are always increasing monthly.

- capital is always increasing.

- increasing the labor force every year

- market growth is always good.

- profit growth is getting better.

- Overall, its financial performance is very good.

- has controlled the market share for the past year.

\section{Intervening Variable}

This research's intervening variable was a product innovation strategy, a strategy built by businesses to make or offer new or different and innovative products to consumers to adjust their tastes and accustomed to changes in the business environment. According to Lukas and Ferrell (2000); Prajogo (2016), to measure the product innovation strategy, the following indicators can be used:

Providing new products that do not yet exist in other competitors

Modifying pre-existing products

Having a high level of product innovation

Using new components in product development

Using new materials in product development

Developing new technologies for increasing product innovation

Developing new product features

\section{Result and Discussion}

The analysis was employed to prove the hypothesis in this study, namely using the Structural Equation Model (SEM) calculation with AMOS 23 software. Before proving the 
hypothesis, this study would describe the respondents' characteristics. The following is the respondents' descriptive analysis:

Table 3 Respondents' Gender

\begin{tabular}{|c|c|c|c|}
\hline Number & Gender & Quantity & Percentage (\%) \\
\hline 1 & \multirow{3}{*}{$\begin{array}{c}\text { Male } \\
\text { Female }\end{array}$} & 93 & $46,5 \%$ \\
\hline 2 & & 107 & $53,5 \%$ \\
\hline Total & & 200 & $100 \%$ \\
\hline \multicolumn{4}{|c|}{ Source: Primary Data (2020) } \\
\hline \multicolumn{4}{|c|}{ Table 4 Respondents' Age } \\
\hline Number & Respondent Age & Quantity & Percentage (\%) \\
\hline 1 & 17-22 year & 34 & $17 \%$ \\
\hline 2 & 23-30 year & 65 & $33 \%$ \\
\hline 3 & $>30$ year & 101 & $51 \%$ \\
\hline Total & & 200 & $100 \%$ \\
\hline
\end{tabular}

Source: Primary Data (2020)

Table 5 Respondents of MSME Industry Sector

\begin{tabular}{cccc}
\hline Number & Industry Sector & Quantity & Percentage (\%) \\
\hline $\mathbf{1}$ & Handicraft & 74 & $\mathbf{3 7 \%}$ \\
$\mathbf{2}$ & Culinary & 89 & $\mathbf{4 5 \%}$ \\
$\mathbf{3}$ & Fashion & 37 & $\mathbf{1 9 \%}$ \\
Total & & 200 & $\mathbf{1 0 0 \%}$ \\
\hline
\end{tabular}

Source: Primary Data (2020)

Table 6 MSMEs' Age

\begin{tabular}{rccc}
\hline No & MSME Age & Quantity & Percentage $(\%)$ \\
\hline $\mathbf{1}$ & $0-1$ Year & 27 & $\mathbf{1 4 \%}$ \\
$\mathbf{2}$ & $2-5$ Years & 94 & $\mathbf{4 7 \%}$ \\
$\mathbf{3}$ & 6-5 Years & 40 & $\mathbf{2 0 \%}$ \\
$\mathbf{4}$ & $>10$ Years & 39 & $\mathbf{2 0 \%}$ \\
\hline Total & & 200 & $\mathbf{1 0 0 \%}$ \\
\hline
\end{tabular}

Source: Primary Data (2020)

Table 7 Turnover of Month

\begin{tabular}{|clcc|}
\hline Number & Turnover of Month & Quantity & Percentage (\%) \\
\hline $\mathbf{1}$ & $<$ Rp 5.000.000 & 48 & $\mathbf{2 4 \%}$ \\
$\mathbf{2}$ & Rp 5.000.000 -Rp 10.000.000 & 12 & $\mathbf{6 \%}$ \\
$\mathbf{3}$ & Rp 10.100.000 - Rp 50.000.000 & 77 & $\mathbf{3 8 . 5 \%}$ \\
$\mathbf{4}$ & Rp 50.100.000-Rp 100.000.000 & 29 & $\mathbf{1 4 . 5 \%}$ \\
$\mathbf{5}$ & Rp 200.100.000-Rp 500.000.000 & 29 & $\mathbf{1 4 . 5 \%}$ \\
$\mathbf{6}$ & Rp 500.100.000-Rp 1.000.000.000 & 5 & $\mathbf{2 . 5 \%}$ \\
\hline Total & & 200 & $\mathbf{1 0 0 \%}$ \\
\hline
\end{tabular}

Source: Primary Data (2020) 
Table 8 Employees' Quantity

\begin{tabular}{rccc}
\hline Number & Quantity of Employees & Quantity & Percentage (\%) \\
\hline $\mathbf{1}$ & $1-5$ People & 123 & $\mathbf{6 2 \%}$ \\
$\mathbf{2}$ & 6-10 People & 49 & $\mathbf{2 4 , 5 \%}$ \\
$\mathbf{3}$ & $>10$ People & 28 & $\mathbf{1 3 , 5 \%}$ \\
Total & & 200 & $\mathbf{1 0 0 \%}$ \\
\hline
\end{tabular}

Source: Primary Data (2020)

The next analysis was the analysis using the Structural Equation Model (SEM) calculation with AMOS 23 software. The sequence of the analysis steps included:

Normality Test Results

Table 9 Normality Test

\begin{tabular}{|c|c|c|c|c|c|c|}
\hline Variable & $\min$ & $\max$ & skew & c.r. & kurtosis & c.r. \\
\hline KP7 & 2,000 & 5,000 &,- 990 & $-5,716$ & ,344 & ,994 \\
\hline KP6 & 2,000 & 5,000 &,- 910 & $-5,253$ & ,454 & 1,310 \\
\hline KP5 & 2,000 & 5,000 &,- 690 & $-3,984$ & 119 & ,344 \\
\hline KP4 & 2,000 & 5,000 &,- 768 & $-4,436$ & 258 & ,745 \\
\hline KP3 & 2,000 & 5,000 &,- 701 & $-4,050$ &,- 099 &,- 285 \\
\hline KP2 & 2,000 & 5,000 &,- 494 & $-2,849$ &,- 400 & $-1,155$ \\
\hline KP1 & 2,000 & 5,000 &,- 725 & $-4,187$ &,- 075 &,- 216 \\
\hline LD7 & 2,000 & 5,000 &,- 815 & $-4,706$ & 220 & ,635 \\
\hline LD6 & 2,000 & 5,000 &,- 790 & $-4,561$ & 183 & ,529 \\
\hline LD5 & 2,000 & 5,000 &,- 961 & $-5,549$ & 093 & 267 \\
\hline LD4 & 2,000 & 5,000 &,- 637 & $-3,678$ & ,054 & 156 \\
\hline LD3 & 2,000 & 5,000 &,- 768 & $-4,436$ & 258 & ,745 \\
\hline LD2 & 2,000 & 5,000 &,- 696 & $-4,019$ & 125 & ,360 \\
\hline LD1 & 2,000 & 5,000 &,- 566 & $-3,268$ & 098 & 282 \\
\hline SIP1 & 2,000 & 5,000 &,- 691 & $-3,990$ & ,076 & ,221 \\
\hline SIP2 & 2,000 & 5,000 &,- 802 & $-4,629$ & 349 & 1,006 \\
\hline SIP3 & 2,000 & 5,000 &,- 566 & $-3,265$ &,- 144 &,- 415 \\
\hline SIP4 & 2,000 & 5,000 &,- 758 & $-4,376$ &,- 063 &,- 181 \\
\hline SIP5 & 2,000 & 5,000 &,- 876 & $-5,058$ & 206 & ,596 \\
\hline SIP6 & 2,000 & 5,000 &,- 677 & $-3,907$ & ,345 & ,996 \\
\hline SIP7 & 2,000 & 5,000 &,- 668 & $-3,857$ & ,069 & 199 \\
\hline Multivariate & & & & & 10,339 & 2,352 \\
\hline
\end{tabular}

Source: Primary Data (2020)

The normality test results in Table 9 show that the multivariate CR value was 2.352. Therefore, the CR value was in the range \pm 2.58 . Therefore, the data in this study could be said to be normally distributed. 
Dari \& Isfianadewi

Product Innovation Strategy and Dynamic Environment Against ...

Outliers Test Results

Table 10 Outliers Test

\begin{tabular}{llll}
\hline Observation number & Mahalanobis d-squared & $p 1$ & $p 2$ \\
\hline $\mathbf{9 1}$ & 45,082 &, 002 & $\mathbf{2 8 7}$ \\
$\mathbf{1 0 2}$ & 40,274 &, 007 & $\mathbf{4 0 1}$ \\
$\mathbf{1 3 5}$ & 37,402 &, 015 & $\mathbf{, 5 8 4}$ \\
$\mathbf{6 9}$ & 36,375 &, 020 & $\mathbf{, 5 6 2}$ \\
$\mathbf{1 5 5}$ & 36,054 &, 022 & $\mathbf{, 4 3 3}$ \\
$\mathbf{1 5 8}$ & 35,447 &, 025 & $\mathbf{3 9 1}$ \\
$\mathbf{1 3 4}$ & 34,271 &, 034 & $\mathbf{, 5 1 9}$ \\
$\mathbf{8 7}$ & 34,004 &, 036 & $\mathbf{4 3 8}$ \\
$\mathbf{1 7 2}$ & 33,465 &, 041 & $\mathbf{4 4 5}$ \\
$\mathbf{1 5 7}$ & 33,382 &, 042 & $\mathbf{3 3 6}$ \\
$\mathbf{8 6}$ & 32,167 &, 056 & $\mathbf{5 7 5}$ \\
$\mathbf{9 5}$ & 32,113 &, 057 & $\mathbf{4 7 0}$ \\
\hline
\end{tabular}

Source: Primary Data (2020)

In table 10, it was found that there were values more than 38.93 , namely data 91 and 102. Data containing outliers should be removed, and after the data was removed, it could be concluded that there were no outliers data.

Confirmatory Test Results

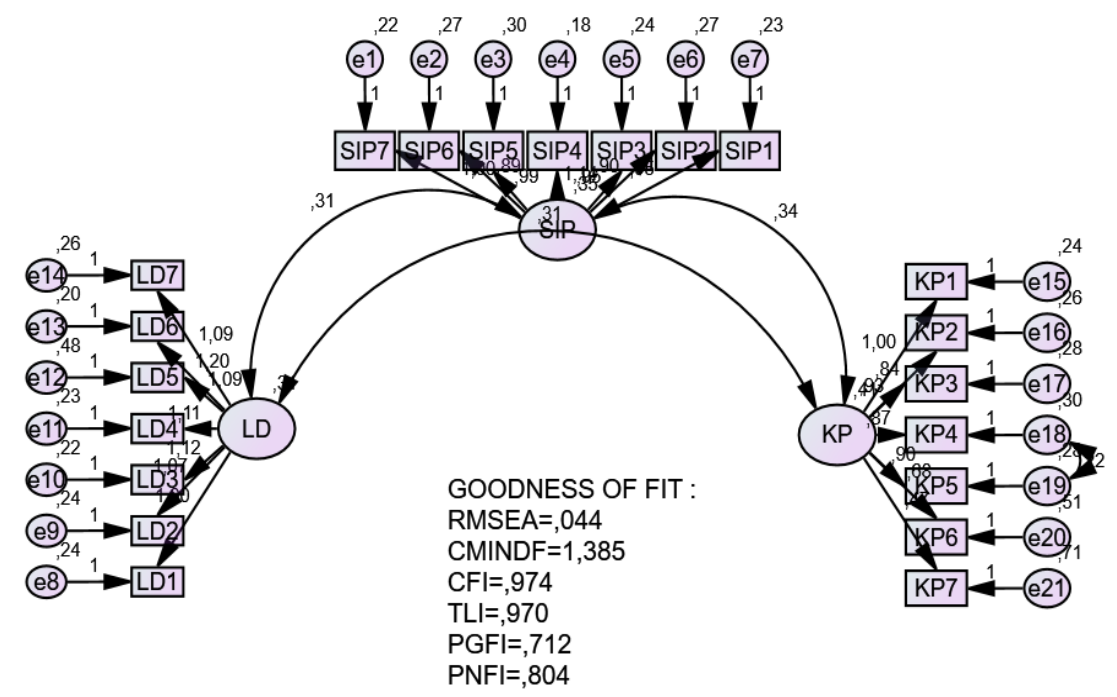

Figure 2 Confirmatory Analysis Results

Source: Primary Data (2020) 
With the loading factor values, as in table 11:

Table 11 Loading Factor Value

\begin{tabular}{|c|c|c|c|}
\hline \multicolumn{4}{|c|}{ Estimate } \\
\hline SIP7 & $<---$ & SIP & ,786 \\
\hline SIP6 & $<---$ & SIP & ,714 \\
\hline SIP5 & $<---$ & SIP & ,730 \\
\hline SIP4 & $<---$ & SIP & 849 \\
\hline SIP3 & $<--$ & SIP & 756 \\
\hline SIP2 & $<---$ & SIP & ,717 \\
\hline SIP1 & $<---$ & SIP & ,763 \\
\hline LD1 & $<---$ & LD & 753 \\
\hline LD2 & $<---$ & LD & ,772 \\
\hline LD3 & $<---$ & LD & ,802 \\
\hline LD4 & $<---$ & LD & 791 \\
\hline LD5 & $<---$ & LD & 659 \\
\hline LD6 & $<---$ & LD & ,831 \\
\hline LD7 & $<---$ & LD & 767 \\
\hline KP1 & $<---$ & $\mathrm{KP}$ & 795 \\
\hline KP2 & $<---$ & $K P$ & ,725 \\
\hline KP3 & $<---$ & $\mathrm{KP}$ & ,750 \\
\hline KP4 & $<---$ & $\mathrm{KP}$ & 714 \\
\hline KP5 & $<---$ & $\mathrm{KP}$ & 740 \\
\hline KP6 & $<---$ & $\mathrm{KP}$ & ,422 \\
\hline KP7 & $<---$ & $\mathrm{KP}$ & ,340 \\
\hline
\end{tabular}

Source: Primary Data (2020)

From the analysis, it was found that there were two indicators with loading factor values below 0.5 , namely KP6 and KP7. They should be removed from the analysis. After two invalid indicators were deleted, all indicators in this study could be said to be valid.

The Goodness of Fit Test Results

Table 12 The goodness of Fit Confirmatory Factor Analysis

\begin{tabular}{lllll}
\hline Fit Indeks & Goodness of Fit & Criteria & Cut-off value & Explanation \\
\hline Absolute Fit & RMSEA & $\leq 0.08$ & 0.044 & Fit \\
& CMINDF & $\leq 2,00$ & 1,385 & Fit \\
Incremental Fit & TLI & $\geq 0.90$ & 0.974 & Fit \\
& CFI & $\geq 0.90$ & 0.970 & Fit \\
Parsimony Fit & PGFI & $\geq 0.60$ & 0.712 & Fit \\
& PNFI & $\geq 0.60$ & 0.804 & Fit \\
\hline
\end{tabular}

Source: Primary Data (2020)

From the goodness of fit test results in Table 12, it appears that all the criteria have been fulfilled. Thus, it could be said that the model in this study has been fit. 


\section{Reliability Test Result}

The reliability coefficient ranges from $0-1$, so the higher the coefficient (close to number 1 ), the more reliable the measuring instrument. It is good construct reliability if construct reliability value $>0.7$ and extracted variance value $>0.5$. From the calculation, the results obtained as Table 13:

Table 13 Reliability Test

\begin{tabular}{|c|c|c|c|c|c|c|}
\hline Variable & Indicator & $\begin{array}{l}\text { Loading } \\
\text { Standard }\end{array}$ & $\begin{array}{l}\text { Loading } \\
\text { Standards }{ }^{2}\end{array}$ & $\begin{array}{l}\text { Measurement } \\
\text { Error }\end{array}$ & CR & VE \\
\hline \multirow{2}{*}{$\begin{array}{l}\text { Strategy } \\
\text { Innovation }\end{array}$} & SIP7 & 0,786 & 0,618 & 0,382 & \multirow[t]{7}{*}{0,9} & \multirow[t]{7}{*}{0,6} \\
\hline & SIP6 & 0,714 & 0,510 & 0,490 & & \\
\hline \multirow[t]{5}{*}{ Product } & SIP5 & 0,730 & 0,533 & 0,467 & & \\
\hline & SIP4 & 0,849 & 0,721 & 0,279 & & \\
\hline & SIP3 & 0,756 & 0,572 & 0,428 & & \\
\hline & SIP2 & 0,717 & 0,514 & 0,486 & & \\
\hline & SIP1 & 0,763 & 0,582 & 0,418 & & \\
\hline \multirow{7}{*}{$\begin{array}{l}\text { Environment } \\
\text { Dynamic }\end{array}$} & LD1 & 0,753 & 0,567 & 0,433 & \multirow{7}{*}{0,9} & \multirow[t]{7}{*}{0,6} \\
\hline & LD2 & 0,772 & 0,596 & 0,404 & & \\
\hline & LD3 & 0,802 & 0,643 & 0,357 & & \\
\hline & LD4 & 0,791 & 0,626 & 0,374 & & \\
\hline & LD5 & 0,659 & 0,434 & 0,566 & & \\
\hline & LD6 & 0,831 & 0,691 & 0,309 & & \\
\hline & LD7 & 0,767 & 0,588 & 0,412 & & \\
\hline \multirow{5}{*}{$\begin{array}{l}\text { The } \\
\text { performance } \\
\text { Company }\end{array}$} & KP1 & 0,795 & 0,632 & 0,368 & \multirow[t]{5}{*}{0,9} & \multirow[t]{5}{*}{0,6} \\
\hline & KP2 & 0,725 & 0,526 & 0,474 & & \\
\hline & KP3 & 0,750 & 0,563 & 0,438 & & \\
\hline & KP4 & 0,714 & 0,510 & 0,490 & & \\
\hline & KP5 & 0,740 & 0,548 & 0,452 & & \\
\hline
\end{tabular}

Source: Primary Data (2020)

From Table 13, it can be seen that all variables' construct reliability had already shown $\geq$ 0.7 . As for the variance extracted in this study, each variable also had a value above 0.5. Therefore, it could be concluded that the questionnaire used for this study was declared reliable.

Model Modification and Complete GOF Test Model Result

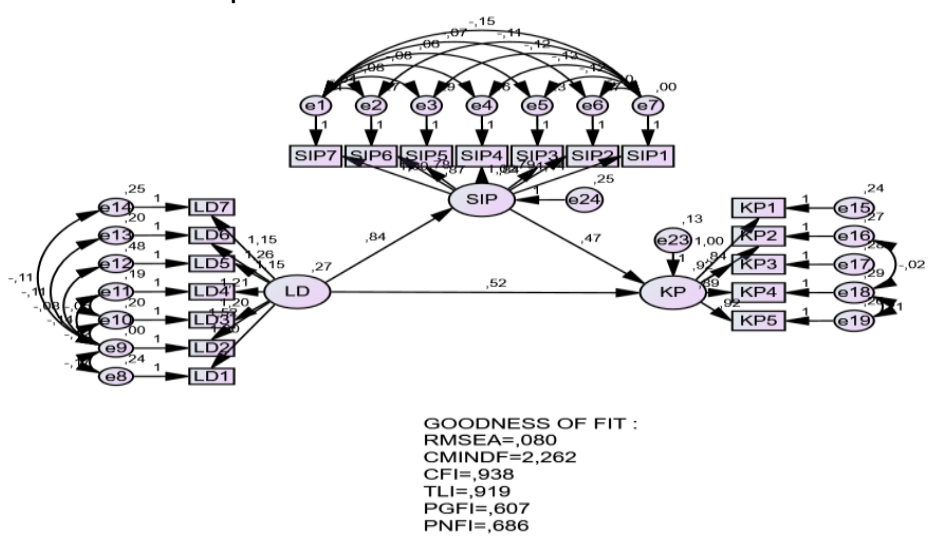

Figure 3 Final Model Path Diagram

Source: Primary Data (2020) 
The goodness of fit test results has shown that all criteria have been met. Besides, the model could be said to Fit, as in Table 14:

Table 14 The Goodness of Fit Test

\begin{tabular}{lllll}
\hline Fit Indeks & Goodness of Fit & Criteria & Cut-off value & Explanation \\
\hline Absolute Fit & RMSEA & $\leq 0.08$ & 0.080 & Fit \\
& CMINDF & $\leq 2,00$ & 2,262 & Marginal Fit \\
Incremental Fit & TLI & $\geq 0.90$ & 0.938 & Fit \\
& CFI & $\geq 0.90$ & 0.919 & Fit \\
Parsimony Fit & PGFI & $\geq 0.60$ & 0.607 & Fit \\
& PNFI & $\geq 0.60$ & 0.686 & Fit \\
\hline
\end{tabular}

Source: Primary Data (2020)

Hypothesis Testing Result

The next analysis was the Structural Equation Model (SEM) analysis in a full model to test the hypotheses developed in this study. The regression weight test results in this study are as in table 15:

Table 15 Regression Weight Test Results

\begin{tabular}{lllllllll}
\hline & & & & Estimate & S.E. & C.R. & P & Label \\
\hline H1 & SIP & $<---$ & LD &, 843 &, 096 & 8,756 & $* * *$ & \\
H2 & KP & $<---$ & SIP &, 474 &, 070 & 6,812 & $* * *$ \\
H3 & KP & $<---$ & LD &, 521 &, 082 & 6,322 & $* * *$ \\
\hline
\end{tabular}

Source: Primary Data (2020)

The hypothesis accepted or rejected could be seen at the Critical Ratio (CR) value, and the probability value $(P)$ from the data processing results. If the test results show a $C R$ value above 1.96 and a probability value $(P)$ below $0.05 / 5 \%$, the proposed research hypothesis is accepted. In detail, the research hypothesis testing was discussed in stages according to the hypothesis that has been proposed. In this research, four hypotheses were proposed, the discussion of which is elaborated as follows:

$\boldsymbol{H}_{1} \quad$ : The dynamic environment positively and significantly impacted product innovation strategies.

$\mathrm{H}_{2} \quad$ : Product innovation strategy positively and significantly affected company performance.

$\mathrm{H}_{3} \quad$ : The dynamic environment positively and significantly influenced company performance. 


\section{Mediation Testing}

Mediation testing was seen from the significance of the indirect effect between variables, seen from the indirect effect-two-tailed significance table. The indirect effects' analysis results are in Table 16:

Table 16 Mediation Test Results

\begin{tabular}{|c|c|c|c|}
\hline & LD & SIP & $\overline{K P}$ \\
\hline LD $\rightarrow$ SIP $\rightarrow$ KP & $\ldots$ & ,004 & $\ldots$ \\
\hline
\end{tabular}

Source: Primary Data (2020)

Based on Table 16, it could be concluded that:

$\boldsymbol{H}_{4}$ : Product innovation strategies mediated the relationship between dynamic environments and company performance.

\section{Discussion}

The relationship between dynamic environmental variables and the product innovation strategy

The analysis results proved a significant and positive influence between the relationship of dynamic environment to the product innovation strategy at MSME in Kulon Progo district. Dynamic environments are characterized by technological changes, variations in customer preferences, changes in product demand, and changes' uncertainty (Jansen et al., 2009). Companies' dynamic environment can encourage companies to engage in the exploitation and exploration of innovation simultaneously (Chang, Hughes, \& Hotho, 2011). As a result, to remain competitive in a dynamic environment, companies must pursue exploitation activities and develop new products and services as they already exist; otherwise, they will quickly become obsolete.

Product innovation is the process of introducing new products and the level of the newness of customer perception about new products. Product innovation implies increased benefits for customers related to functional or other improvements in products or services (Zaefarian, Forkmann, Mitręga, \& Henneberg, 2017). Based on the above conclusions, that MSME involved in Kulon Progo district is in line with the above theory, where MSME owners could adapt to the surrounding environment, directly influencing the operating businesses. Thus, those changes in the environment made a business strive for a strategy product innovation to meet customers' needs and desires.

This research has proven that the dynamic environment influenced the product innovation strategy at SMEs in Kulon Progo Regency. This research is in line with previous research conducted by Tsai and Yang (2013), where the research proved a significant influence of a dynamic environment on innovation. In line with Prajogo (2016) research, the study's results indicated that the dynamic environment was 
Dari \& Isfianadewi

Product Innovation Strategy and Dynamic Environment Against ...

positively related to product innovation strategies in manufacturing companies in Australia.

\section{The relationship of product innovation strategy variables to company performance}

Based on the analysis results, it was proved that there was a significant and positive influence between the relationship of product innovation strategies to company performance at MSME in Kulon Progo district. The product innovation strategy is the scope of product improvements, such as small changes to existing products and new product development. Then, it is essential to understand how to develop new products. The company's new product development must succeed successfully (Zaefarian et al., 2017). Product innovation is successfully considered with the entire company's performance. Without successful product innovation, most companies will not be able to improve their performance. Therefore, from an innovative perspective, product innovation is the success of making innovative offers. If it is successfully applied, it will be deemed valuable by the customer.

Company performance is a picture of a company that can explain the situation of its performance results, for organizations or companies looking for profit, stability, and improvement in economic situations that ensure the commercial continuity of the company (Rehman, 2018). Based on these explanations, MSME operating in Kulon Progo district is in line with the theory explained above; namely, the MSMEs' owners realized the importance of implementing product innovation strategies to meet customers' needs and desires. It directly influenced company performance. Thus, with innovation, these products made MSME owners able to maintain or improve their performance.

This research proves that the product innovation strategy impacted its performance at MSME in Kulon Progo Regency. This research is supported by previous research conducted by Heimonen (2012); Rosenbusch, Brinckmann, and Bausch (2011) that SMEs are very innovation-oriented to develop innovative products and services; thereby, increasing the ability of innovation and offering in markets that influence company performance. Zehir, Altindag, and Acar (2011) suggest that companies that encourage the creation and introduction of new products or technologies often have superior performance results. The current research underlines the importance of innovative behavior that must be owned by the MSMEs' owners.

\section{Relationship between dynamic environment variables and company performance}

Based on the analysis results, it was confirmed that there was a significant and positive influence between the relationship of the dynamic environment on company performance at MSME in Kulon Progo district. A dynamic environment is a change marked by technological changes, variations in customer preferences, demand fluctuations; in this case, the dynamic environment causes uncertainty that leads to anxiety in the company (Jansen et al. 2009). Based on these explanations, it is clear that the dynamic environment is influenced by external factors; external factors will describe the level and stability of each company's environmental changes. 
Company performance is the company's ability to achieve its goals by efficiently and effectively using all company resources (Arshad \& Arshad, 2019). Company performance can be measured by using a comparison between actual output and input. Therefore, performance measurement allows organizations to emphasize units that need improvement by assessing the level of work progress in terms of cost, time, and quality together by utilizing the capacity of a larger output (Pesalj, Pavlov, \& Micheli, 2018). Based on these explanations, MSME in Kulon Progo district is in line with the theory explained above. MSMEs' owners realized the importance of adapting to dynamic environments because it influenced company performance.

This study proved that a dynamic environmental influenced company performance at MSME in Kulon Progo district. This study is in line with research conducted by Munizu (2010) that a dynamic environment influenced by external factors consisted of government policies, social economy, culture, and aspects of the related institutions' role, which had a significant and positive effect on the MSEs' performance in South Sulawesi. Research with the same analysis results was also conducted by (Boyne \& Meier, 2009). The dynamic environment displayed by environmental turbulence when unexpected changes occurred. The greater the unexpected changes, the greater the negative impact on company performance. If a company can predict and adapt to changes in its environment, it will positively impact company performance.

The variable relationship of the product innovation strategy mediates the relationship between the dynamic environment and company performance

Based on the analysis results, it was verified that there was a positive and significant effect on the relationship of a dynamic environment and company performance mediated by the product innovation strategy at MSME in the Kulon Progo district. (Valencia, Valle, \& Jimenez, 2010) underlined that innovation determinants can be grouped as individual factors, organizational factors, and environmental factors. Environmental turbulence is the most critical feature of the contemporary business environment. Environmental turbulence with a dynamic environment has in common that it is influenced by external factors and unexpected environmental changes (Wong, 2014); (Tsai \& Yang, 2014); (Wheelen \& Hunger, 2012).

Tsai and Yang (2014) note that environmental changes can produce opportunities and obstacles to innovation. Alexiev, Volberda, and Bosch (2016) state that environmental turbulence is an aspect of the organizational environment associated with innovation. Wong (2014) affirms that environmental turbulence forces companies to leave their comfort zones and compete with new capabilities and offerings that present opportunities to develop new products, master new technologies, engage with new customers, and reach new markets at additional costs, which ultimately increase company performance. 


\section{Conclusion}

In data management, it was known that there was a positive and significant influence of dynamic environments on product innovation strategies at MSME at Kulon Progo. It was because MSMEs' owners in the Kulon Progo district realized the importance of adapting to a very dynamic environment and the ability to adapt to the environment that will encourage them to carry out product innovation strategies.

In managing data, it was known that there was a positive and significant influence between product innovation strategies and company performance at MSME in Kulon Progo district. It was because the MSMEs' owners in the Kulon Progo district realized the importance of implementing a product innovation strategy to meet customers' various needs and desires, which would have an impact on the always good company's performance.

Data management showed a positive and significant influence between dynamic environments on company performance at MSME in Kulon Progo district. It was because the MSMEs' owners in the Kulon Progo district realized the importance of adapting to a challenging predicted environment to have a positive impact on company performance.

Data management revealed that product innovation strategies positively and significantly mediated the relationship between dynamic environments and company performance. It was because the MSMEs' owners in the Kulon Progo district realized the importance of adapting to changes in a very dynamic environment so that this ability would improve company performance by implementing a product innovation strategy.

\section{References}

Abdul. (2019). Kemenkop Perkuat Kemitraan Koperasi dan Usaha Mikro Kecil Menengah Kulon Progo Dengan Usaha Besar. Retrieved November 13, 2019, from https://www.indotimes.co.id/14562/2019/03/24/kemenkop-perkuat-kemitraankumkm-kulon-progo-dengan-usaha-besar/

Acosta, P. ., Popa, S., \& Conesa, I. M. (2018). Information technology, knowledge management and environmental dynamism as drivers of innovation ambidexterity: a study in SMEs. Journal of Knowledge Management, 22(4), 824-849. https://doi.org/10.1108/JKM-10-2017-0448

Alexiev, A. S., Volberda, H. W., \& Bosch, F. A. J. (2016). Interorganizational collaboration and firm innovativeness: Unpacking the role of the organizational environment. Journal of Business Research, 69(2), 974-984. https://doi.org/10.1016/i.jbusres.2015.09.002

Arshad, M. Z., \& Arshad, D. (2019). Internal capabilities and SMEs performance: A case of textile industry in Pakistan. Management Science Letters, 9(4), 621-628. https://doi.org/10.5267/j.msl.2019.1.001

BAPPEDA DIY. (2019). Data Jumlah UMKM di Wilayah DIY. Retrieved February 25, 2020, from http://bappeda.jogjaprov.go.id/dataku/data dasar/index/107-ukm 


\section{Dari \& Isfianadewi}

Product Innovation Strategy and Dynamic Environment Against ...

Boyne, G. A., \& Meier, K. J. (2009). Environmental turbulence, organizational stability, and public service performance. Administration and Society, 40(8), 799-824. https://doi.org/10.1177/0095399708326333

Budiarto, D. S., Prabowo, M. A., \& Herawan, T. (2017). An integrated information system to support supply chain management \& Performance in SMEs. Joumal of Industrial Engineering and Management, 10(2), 373-387. https://doi.org/10.3926/jiem.2180

Carranza, J. E. (2010). Product innovation and adoption in market equilibrium: The case of digital cameras. International Journal of Industrial Organization, 28(6), 604-618. https://doi.org/10.1016/i.ijindorg.2010.02.003

Chang, Y. ., Hughes, M., \& Hotho, S. (2011). Internal and external innovation ambidexterity antecedents of SMEs' outcomes. Management Decision, 49(10), 1658-1676. https://doi.org/10.1108/00251741111183816

Corsino, M., \& Gabriele, R. (2010). Product innovation and firm growth: Evidence from the integrated circuit industry. Industrial and Corporate Change, 20(1), 29-56. https://doi.org/10.1093/icc/dtq050

Dibrell, C., Davis, P. S., \& Craig, J. (2008). Fueling Innovation through Information Technology in SMEs. Journal of Small Business Management, 46(2), 203-218. https://doi.org/10.1111/j.1540-627X.2008.00240.x

Dinas Koperasi dan UMKM. (2019). Data UMKM Berdasarkan Sektor Ekonomi Kab/Kota Kulon Progo.

Fontana, R., \& Nesta, L. (2009). Product innovation and survival in a high-tech industry. Review of Industrial Organization, 34(4), 287-306. https://doi.org/10.1007/s11151-009$\underline{9210-7}$

Hair Jr, J. F., Black, W. C., Babin, B. J., \& Anderson, R. E. (2014). Multivariate Data Analysis (7th ed.). New Jersey: Pearson Education, Inc.

Han, C., \& Gao, S. (2019). A Chain Multiple Mediation Model Linking Strategic, Management, and Technological Innovations to Firm Competitiveness, 21(5), 879-905. https://doi.org/10.7819/rbgn.v21i5.4030

Heimonen, T. (2012). What are the factors that affect innovation in growing SMEs? European Journal of Innovation Management, 15(1), 122-144. https://doi.org/10.1108/14601061211192861

Jansen, J. J. P., Vera, D., \& Crossan, M. (2009). Strategic leadership for exploration and exploitation: The moderating role of environmental dynamism. Leadership Quarterly, 20(1), 5-18. https://doi.org/10.1016/j.leaqua.2008.11.008

Kementerian Koperasi. (2019). Rencana strategis sekretariat kementerian koperasi dan usaha kecil dan menengah republik indonesia tahun 2015 - 2019.

Klein, \& Sorra. (1996). Strategic Brand Management: Building, Measuring, \& Managing Brand Equity. Jakarta: Salemba Empat.

Kusiak, A. (2009). Innovation: A data-driven approach. International Journal of Production Economics, 122(1), 440-448. https://doi.org/10.1016/i.ijpe.2009.06.025

Lee, S. M., Kim, J., Choi, Y., \& Lee, S. (2009). Effects of IT knowledge and media selection on operational performance of small firms. Small Business Economics, 32(3), 241-257. https://doi.org/10.1007/s11187-007-9095-5

Lukas, \& Ferrell, O. . (2000). The Effect of Market Orientation on Product Innovation. Intergovernmental Panel on Climate Change, 28(2), 239-247. https://doi.org/10.1017/CBO9781107415324.004

Moeheriono. (2012). Competency Based Performance Measurement. Jakarta: Raja Grafindo Persada.

Muchlas, Z. (2015). Strategi Inovasi Dan Daya Saing Industri Kecil Menengah (IKM) Agro Industri Di Kota Batu. Jumal JIBEKA, 9(2), 78-91. Retrieved from http://galeriukm.web.id/news/kriteria-usaha-mikro- 


\section{Dari \& Isfianadewi}

Product Innovation Strategy and Dynamic Environment Against ...

Munizu, M. (2010). Pengaruh Faktor-Faktor Eksternal dan Internal Terhadap Kinerja Usaha Mikro dan Kecil (UMK) di Sulawesi Selatan. Jurnal Manajemen Dan Kewirausabaan, 12(1), 33-41. https://doi.org/10.9744/jmk.12.1.pp.33-41

Omri, W. (2015). Innovative behavior and venture performance of SMEs: The moderating effect of environmental dynamism. European Journal of Innovation Management, 18(2), 195-217. https://doi.org/10.1108/EJIM-02-2013-0015

Pesalj, Pavlov, \& Micheli, P. (2018). The use of management control and performance measurement systems in SMEs: A levers of control perspective. International Journal of Operations and Production Management, 38(11), 2169-2191. https://doi.org/10.1108/IJOPM-09-2016-0565

Popa, S., Acosta, P. ., \& Conesa, I. (2017). Antecedents, moderators, and outcomes of innovation climate and open innovation: An empirical study in SMEs. Technological Forecasting and Social Change, 118(March), 134-142. https://doi.org/10.1016/j.techfore.2017.02.014

Prajogo, D. I. (2016). The strategic fit between innovation strategies and business environment in delivering business performance. International Journal of Production Economics, 171, 241-249. https://doi.org/10.1016/j.ijpe.2015.07.037

Raju, P. S., Lonial, S. C., \& Crum, M. D. (2011). Market orientation in the context of SMEs: A conceptual framework. Journal of Business Research, 64(12), 1320-1326. https://doi.org/10.1016/i.jbusres.2010.12.002

Rehman, M. ., Wong, H. Y., Sultan, P., \& Merrilees, B. (2018). How brand-oriented strategy affects the financial performance of B2B SMEs. Journal of Business and Industrial Marketing, 33(3), 303-315. https://doi.org/10.1108/JBIM-10-2016-0237

Rosenbusch, N., Brinckmann, J., \& Bausch, A. (2011). Is innovation always beneficial? A meta-analysis of the relationship between innovation and performance in SMEs. Journal of Business Venturing, 26(4), 441-457. https://doi.org/10.1016/j.jbusvent.2009.12.002

Sanchez, E. ., Morales, V. J., \& Rojas, R. (2017). Analysis of the influence of the environment, stakeholder integration capability, absorptive capacity, and technological skills on organizational performance through corporate entrepreneurship. International Entrepreneurship and Management Journal, 14(2), 345-377. https://doi.org/10.1007/s11365-017-0436-9

Schweitzer, F. M., Gassmann, O., \& Gaubinger, K. (2011). Open innovation and its effectiveness to embrace turbulent environments. International Journal of Innovation Management, 15(6), 1191-1207. https://doi.org/10.1142/S1363919611003702

Tambunan, T. T. H. (2011). Development of micro, small and medium enterprises and their constraints: A story from Indonesia. International Journal of Business, 13(1), 21-43. https://doi.org/10.22146/gamaijb.5492

Tsai, K. H., \& Yang, S. Y. (2013). Firm innovativeness and business performance: The joint moderating effects of market turbulence and competition. Industrial Marketing Management, 42(8), 1279-1294. https:// doi.org/10.1016/j.indmarman.2013.06.001

Tsai, K. H., \& Yang, S. Y. (2014). The contingent value of firm innovativeness for business performance under environmental turbulence. International Entrepreneurship and Management Journal, 10(2), 343-366. https://doi.org/10.1007/s11365-012-0225-4

UU RI No. 20. (2008). Kriteria UMKM.

Valencia, J. C. N., Valle, R. S., \& Jimenez, D. J. (2010). Organizational culture as determinant of product innovation. European Journal of Innovation Management, 13(4), 466-491. https://doi.org/10.1108/sd.2011.05627dad.006

Wheelen, \& Hunger, D. J. (2012). Strategic Management and Business Policy Concepts and Cases (Eleventh E). USA: Prentice-Hall International. 
Wong, S. K. S. (2014). Impacts of environmental turbulence on entrepreneurial orientation and new product success. European Journal of Innovation Management, 17(2), 229-249. https://doi.org/10.1108/EJIM-04-2013-0032

Wu, L. Y. (2010). Applicability of the resource-based and dynamic-capability views under environmental volatility. Journal of Business Research, 63(1), 27-31. https://doi.org/10.1016/i.jbusres.2009.01.007

Zaefarian, G., Forkmann, S., Mitręga, M., \& Henneberg, S. C. (2017). A Capability Perspective on Relationship Ending and Its Impact on Product Innovation Success and Firm Performance. Long Range Planning, 50(2), 184-199. https://doi.org/10.1016/j.lrp.2015.12.023

Zahra, S. A., \& Das, S. R. (1993). Innovation Strategy and Financial Performance in Manufacturing Companies: an Empirical Study. Production and Operations Management, 2(1), 15-37. https://doi.org/10.1111/j.1937-5956.1993.tb00036.x

Zehir, C., Altindag, E., \& Acar, A. Z. (2011). The Effects of relationship orientation through innovation orientation on firm performance: An empirical study on Turkish familyowned firms. Procedia-Social and Behavior Sciences, 24. 896-908.

https://doi.org/10.1016/j.sbspro.2011.09.024 